\title{
The Application of Cohesive Devices in College English Listening and Speaking Teaching
}

\author{
Qing Li \\ College of Foreign Languages \\ Qingdao Agricultural University \\ Qingdao, China \\ liqingqust@163.com
}

\begin{abstract}
Halliday and Hasan (1976) considered that cohesion, one of the most important characteristic of text, exists within the text. Cohesive devices are mainly embodied by the surface structure in a text and form a tangible network. There should be one or several cohesive devices to transform one paragraph into coherent text. It is on the basis of cohesion theory that an experimental teaching is conducted to explore how to apply these cohesive devices to the teaching of college English listening and speaking and try to testify the teaching effect under the instruction of a Cohesion-focused Approach, suggested by the author and its application and promotion in different levels.
\end{abstract}

Keywords-cohesive devices; text; college English; listening and speaking; application;

\section{INTRODUCTION}

As stipulated in College English Curriculum Requirements (For Trial Implementation, 2004), College English, an integral part of higher learning, is a required basic course for undergraduate students. The objective of College English aims to develop students' ability to use English in an all-round way, especially in listening and speaking, so that in their future work and social interactions they will be able to exchange information effectively through both spoken and written channels. The competence requirements in listening and speaking should be fully considered, and corresponding teaching hours should be adequately allocated in practical teaching. Just as Rost (1994) points out that listening is vital in language learning because it provides input for the learners. Without understanding input at the right level, learning can't begin, especially in the process of facilitating the ability of speaking, while speaking is means of successful communication.

It is found, through the investigation and the teachers' interview, that the existing problems with students' listening lie in that their understanding of the listening materials depends mainly on the recognition of vocabulary and grammar. They don't know how to interpret the acoustic signals and fail to understand the logic between sentences, let alone the main idea of paragraphs or texts. As far as students' speaking is concerned, ambiguous references and expressions are common among students' utterances with illogical and incoherent sentences here and there. Most of the students consider listening and speaking timeconsuming and it is difficult for them to make any great achievements.

Most of the recent researches focus on the listening strategies, listening comprehension and its process instead of the integration of listening and speaking. Many of them emphasize the listening strategy training, schema theory and listening comprehension, top-down processing, bottom-up processing and top-down and bottom-up interactive processing whereas in Western Countries or in China, while researches on speaking are few. Ellis (1994) points out that some researches focus on the influence of learners' motivation and learning strategies on learners' acquisition of speech. Thus the researches on the integration of listening and speaking are few, let alone the researches on the integration of listening and speaking from the perspective of cohesion.

\section{LITERATURE REVIEW}

Halliday and Hasan (1976) states that a text is best regarded as a semantic unit: a unit not of form but of meaning. Thus it is related to a clause or sentence not by size but by realization, the coding of one symbolic system in another. If a passage of English containing more than one sentence is perceived as a text, there will be certain linguistic features present in that passage which can be identified as contributing to its total unity and giving it texture. Any segment of a text can be characterized in terms of the number and kinds of ties contributing to the total unity. The concept of a tie makes it possible to analyze a text in terms of its cohesive properties, and give a systematic account of its patterns if texture. These ties, called cohesive ties, help to make a text coherent and show listeners or readers cohesive chains to follow. They considered that cohesion, one of the most important characteristic of text, exists within the text. Cohesive devices are mainly embodied by the surface structure in a text to form a tangible network and are essential to make a discourse concise and information prominent and logics coherent. There should be one or several cohesive devices to transform one paragraph into coherent text. The potential for cohesion lies in the systematic resources of cohesive devices, regarded as the marks of one coherent text: reference, substitution, ellipsis, conjunction and lexical cohesion, which are built into the language itself. Language doesn't 
exist in the form of isolated words or sentences, but in the coherent discourses. They hold the view that the concept of cohesion is a semantic one and part of the system of language. Hasan develops and expands the concept of cohesion in the book Language, Context and Text (1985) and divides the cohesion theory into two big categories, which are structural and non-structural cohesion.

According to Halliday and Hasan's view, it is known that cohesion is a semantic relation which makes a passage whole and united and combines all the elements of the text to form a single unit. Besides this, cohesion is also a concrete means of achieving unity and snakes a discourse or a text and distinguishes it from a non-text and it also reflects the unity of the discourse or the text. In listening materials, if the listeners can grasp the tangible network from the perspective of cohesive devices, the meaning of the whole text or discourse can be understood. To speaking, one or several cohesive devices which are alike the glue of sentences can help build up different levels of utterances to make the utterances clear and logical.

It is on the basis of cohesion theory that the author conducts the experimental teaching on how to apply these cohesive devices to the teaching of college English listening and speaking, and try to testify the teaching effect under the instruction of a Cohesion-focused Approach, suggested by the author.

\section{EXPERIMENTAL STUDY}

In order to testify the effect of this teaching method, the experimental was carried out in Qingdao Agricultural university.

\section{A. Research Design}

In this experimental teaching, there are 212 non-English major freshmen chosen as subjects. They come from Qingdao Agricultural University. These subjects are divided into two groups: Experiment Group (EG) and Control Group (CG). There are 112 subjects in EG, and 100 subjects in CG. And EG is further divided into EG1and EG2. The subjects in CG are chosen at random in the same grade.

The subjects are not informed of the experimental teaching. The experiment is carried out in the spring term, the second term of their first academic year. There are two periods of class per week. To ensure the reliability and persuasion of experimental teaching, all the sample materials are chosen from the textbook: College English Listening and Speaking Course 2.

It aims to explore how to apply these cohesive devices to the teaching of listening and speaking, and try to testify the teaching effect under the instruction of a Cohesion-focused Approach, suggested by the author.

\section{B. Theoretical Instructions}

The experimental teaching, on the basis of Cohesion Theory is carried out. It starts with a brief systematic introduction of the cohesive devices. Five categories and their functions of cohesive devices are given to the subjects in EG step by step. The subjects are instructed that cohesive devices are mainly embodied by the surface structure in a text and form a tangible network. In the network, these cohesive devices serve as the markers of the surface structure like the "knots" in a net.

The cohesive devices are taught gradually at the first stage of each listening and speaking period. These explanations are followed by the examples that exist in the subjects' listening materials to strengthen and consolidate the knowledge of cohesive devices. In each listening material, the subjects are required to show the cohesive chains according to every cohesive device. All these cohesive chains found by the subjects come together to form a tangible network of one listening material. It is based on the cohesive devices that this experimental teaching method is called the Cohesion-focused Approach.

\section{Application of cohesive devices}

In this stage, the detailed theoretical instructions of cohesion are presented.

Sample 1: (Test 2, Part A, College English Listening and Speaking Course 2, 2002) There are three activities that are especially helpful in improving our ability to understand English. These three activities are listening comprehension, reading comprehension and dictation. Dictation involves the activity of writing down every word we hear. This helps us understand more fully what we listen to. Full understanding does not begin until we hear almost everything and forget what we do not need. But the benefits of doing dictation go beyond just helping us understand better. It also helps with grammar, vocabulary, pronunciation, spelling, punctuation, etc. When there is no teacher around, dictation can effectively help us find out misunderstood points and other mistakes.

Firstly, the students are instructed to highlight the network of the listening passage, as follows:

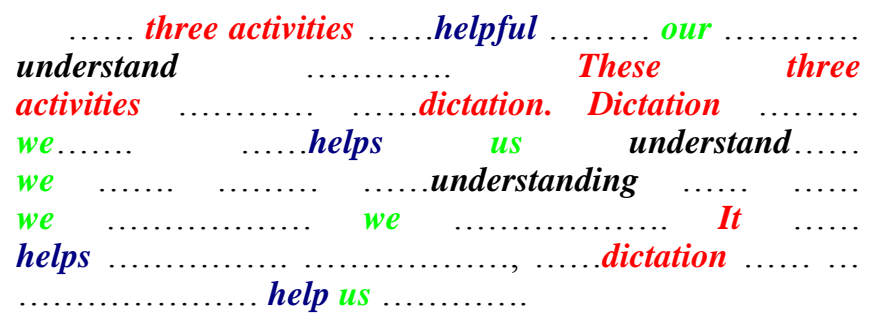

Figure 1. Network of Sample 1

In this network of the listening passage, different colors stand for different cohesive chains of the network. There are four cohesive chains in this passage in total. In view of Cohesion Theory, these four cohesive chains belong to two categories: the reiteration cohesive chains formed by the red, blue and black markers; and the reference cohesive chains formed by markers in green. 


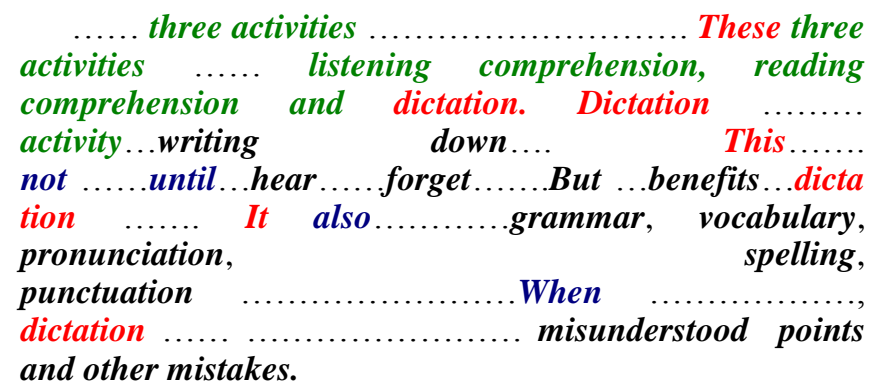

Figure 2. Network of Sample 1

Picture 2 shows the subjects a network of much more detailed information via collocation cohesion and conjunction cohesion. It demonstrates clearly how the cohesive devices contribute to the cohesion of the material.

Secondly, the teacher helps the subjects to grasp the main point through these markers. This short passage is about one of the three activities - dictation. "Dictation" is the subordinate of "three activities". The words in bold letters are markers of reiteration of lexical cohesion. And another kind of marker of reiteration cohesive chains is "help". The reference markers "we", "our", and "us" show students the objects of this listening material. Thus, the main idea comes out: It is the advantage that the passage talks about. Dictation, one of the three activities, is helpful to our understanding. The word "also" is another marker pretty useful for students understanding of main idea. That means "Dictation has another advantage". Therefore, the network helps students grasp the main idea of the listening quickly and accurately.

At the very beginning of this experimental teaching, it is difficult for the subjects to grasp the tangible network quickly, especially to the subjects in lower level. Through a period of instruction, the teaching undergoes a gradual process from simple cohesive chains to complex chains or from one cohesive chain to several cohesive chains in their listening materials.

Thirdly, the teacher gives students analysis of these cohesive surface markers to help them understand step by step so that the students can form the habit to grasp the network when listening. Meanwhile, the instructor chooses several cohesive markers appearing in the listening materials, such as in Sample1, "three", "activity" "dictation", "understand", "but", "and", "also", "when", to make students organize utterances in their own words similar to the original meaning of passage, that is retelling.

To help the students grasp clearly the chains of the network, more samples are chosen for practice by recognizing and analyzing the cohesive devices, and then have the students to retell the listening materials with the cohesive devices to practice speaking.

\section{Data Collection}

Data from the pre-test includes listening scores of the CG, EG1 and EG2. They are collected at the end of the first semester in the first academic year of the subjects.
Meanwhile, spoken utterances of the subjects in EG are recorded.

Data from the post-test includes listening scores of the CG, EG1 and EG2. They are collected after the one-term experimental teaching. After the experimental teaching, the spoken utterances of the subjects in EG are recorded.

\section{RESULTS AND DISCUSSION}

To testify the efficiency of this Cohesion-focused Approach, a comparison is made between the pre-test and the post-test. Each test has four parts which include five short conversations, one long conversation, one short passage and one passage for compound dictation. And the total score is 20 points.

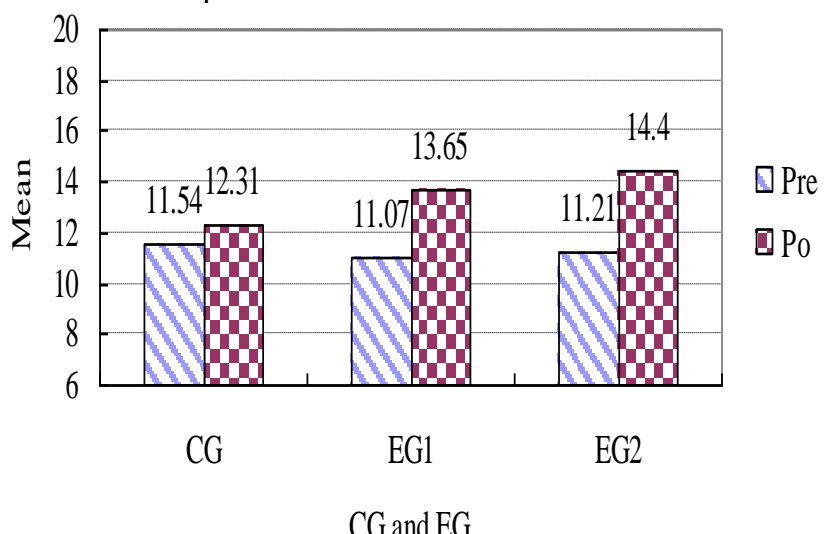

Figure 3. Comparison of means among CG, EG1, EG2

The above graph shows that the subjects are almost in the same level in pre-test, while the means of the subjects in EG1 and EG2 are much higher than that of the subjects in CG. It means that the subjects in EG perform better than the subjects in CG.

\section{A. Comparison of Students' Listening Performance in the Pre-test}

From Table 2, the result of 2-tailed t-test is got, that is, the significance value is 0.280 , which means $P$ value, 0.280 is more than 0.05 . Thus the conclusion can be drawn that there is no significant difference within the EG1 and CG before the experiment.

Table 3 show us another two groups' t-test comparison in the pre-test before the experiment between the EG2 and CG. And in the 2-tailed t-test, $P$ value is 0.437 , which means $P$ value is more than 0.05 . Therefore, the conclusion can be drawn that there is no significant difference within the EG2 and $\mathrm{CG}$ before the experiment. 
TABLE I. INDEPENDENT SAMPLES TEST BETWEEN EG1 AND CG

\begin{tabular}{|c|c|c|c|c|c|c|c|c|c|}
\hline & \multicolumn{9}{|c|}{$\begin{array}{l}\text { Levene'sTest for } \\
\text { Equality of Variances }\end{array}$} \\
\hline & \multirow{2}{*}{ F } & \multirow{2}{*}{ Sig. } & \multirow{2}{*}{$\mathrm{t}$} & \multirow{2}{*}{ Df } & \multirow{2}{*}{$\begin{array}{l}\text { Sig. } \\
\text { (2-tailed) }\end{array}$} & \multirow{2}{*}{$\begin{array}{l}\text { Mean } \\
\text { Difference }\end{array}$} & \multirow{2}{*}{$\begin{array}{l}\text { Std. Error } \\
\text { Difference }\end{array}$} & \multicolumn{2}{|c|}{$\begin{array}{l}95 \% \text { Confidence Interval } \\
\text { of the Difference }\end{array}$} \\
\hline & & & & & & & & Lower & Upper \\
\hline $\begin{array}{l}\mathrm{p} \text { Equal Variances } \\
\text { assumed } \\
\text { Equal Variances } \\
\text { not assumed }\end{array}$ & 3.915 & .076 & $\begin{array}{l}-1.084 \\
-1.011\end{array}$ & $\begin{array}{l}154 \\
92.663\end{array}$ & $\begin{array}{l}.280 \\
.315\end{array}$ & $\begin{array}{l}-.47357 \\
-.47357\end{array}$ & $\begin{array}{l}.43691 \\
.46861\end{array}$ & $\begin{array}{l}-1.33667 \\
-1.40417\end{array}$ & $\begin{array}{l}.38953 \\
.45703\end{array}$ \\
\hline
\end{tabular}

TABLE II. INDEPENDENT SAMPLES TEST BETWEEN EG2 AND CG

\begin{tabular}{|c|c|c|c|c|c|c|c|c|c|}
\hline & \multicolumn{2}{|c|}{$\begin{array}{c}\text { Levene's Test for } \\
\text { Equality of Variances }\end{array}$} & & & & & & & \\
\hline & $\mathrm{F}$ & Sig. & \multirow[t]{2}{*}{$\mathrm{t}$} & \multirow[t]{2}{*}{ Df } & \multirow{2}{*}{$\begin{array}{c}\text { Sig. } \\
\text { (2-tailed) }\end{array}$} & \multirow{2}{*}{$\begin{array}{c}\text { Mean } \\
\text { Difference }\end{array}$} & \multirow{2}{*}{$\begin{array}{l}\text { Std. error } \\
\text { Difference }\end{array}$} & \multicolumn{2}{|c|}{$\begin{array}{c}95 \% \text { Confidence Interval } \\
\text { of the Difference }\end{array}$} \\
\hline & & & & & & & & Lower & Upper \\
\hline $\begin{array}{c}\mathrm{p} \quad \text { Equal Variances } \\
\text { assumed } \\
\text { Equal Variances } \\
\text { not assumed }\end{array}$ & 2.873 & .092 & $\begin{array}{l}-.779 \\
-.738\end{array}$ & $\begin{array}{c}154 \\
97.216\end{array}$ & $\begin{array}{l}.437 \\
.462\end{array}$ & $\begin{array}{l}-.33071 \\
-.33071\end{array}$ & $\begin{array}{l}.42478 \\
.44814\end{array}$ & $\begin{array}{l}-1.1698 \\
-1.2201\end{array}$ & $\begin{array}{l}.50842 \\
.55869\end{array}$ \\
\hline
\end{tabular}

\section{B. Comparison of Students' Listening Performance in the Post-test}

Independent Samples Test between EG1 and CG shows the results between the EG1 and CG in the post-test. And the 2-tailed t-test presented the significant value is 0.000 , which is less than 0.05 . It means that there is a significant difference between the EG1 and CG in the post-test. The conclusion can be drawn that the students in EG1 have improved their listening ability after they received the cohesion-focused teaching method in listening, while the students in CG have barely improved in their listening ability.

Another two groups' data are also calculated in the Independent Samples Test, and from the Independent Samples 2-tailed T-test, it can be drawn that there is a significant difference between the EG2 and CG in the posttest after the teaching experiment, because of $\mathrm{P}=0.000$ $<0.05$.

The above analysis indicated that after the teaching experiment and the analysis of the data of post-test, the students in the EG have made much more progress than the students in the CG.

With the analysis of subjects' spoken discourses and interview, it can be found that the subjects grasp them step by step so that they apply these cohesive markers to form the tangible network in their logical and coherent utterances.

\section{CONCLUSION}

The results indicate that most students have transferred their attention from vocabulary and sentences to the understanding of the whole text. They come to know how to grasp the main idea and the detailed information through the tangible network of cohesive devices within the text. Meanwhile, most students are able to organize their utterances in clear and logical order and make their utterances coherent and comprehensive. Great progress has been made in the students' performance which is a good illustration of the feasibility of this experimental teaching. It is true that some students of lower level still have difficulty in understanding listening materials and fail to achieve the above performance.

It has been proved that the "Cohesion-focused Teaching Method" can help students promote their ability in mastering and understanding language in use to improve the communication competence. In view of the instructive value of the approach, it might as well a good trial for the peers in their creative teaching of listening and speaking.

Application and Promotion

Since the good effect of "Cohesion-focused Teaching Method", the research findings were used to the teaching of listening and speaking in English major, postgraduate English teaching and vocational English teaching. While teaching, the teac hing has been improved.

In the process of teaching, the teachers first focused on the cohesive devices to consolidate the ideas of cohesion both in their listening and in speaking. Then the students gradually recognized the cohesive methods and devices hidden in the oral and written passage. They used these cohesive devices to find the tangible network within the text to help them understand. After the application of the 
"Cohesion-focused Teaching Method", the students listening and speaking ability has been improved.

With the application of the research findings, the throughput rates both in the College English Test Band 4, Band 6 and Test of English Major Band 4 are more than $20 \%$ above the national wide average rate. And the throughput rate in Test of English Major Band 8 has been increased to $72.48 \%$ from $55.4 \%$ in 2012 , which was more than $30 \%$ above the national wide average rate.

Meanwhile, the oral level in the second language has been improved continuously with the improvement of listening ability. The throughput rate in oral test has come up to $58 \%$ from $15 \%$ in 2012 .

Last but not the least, with the listening and speaking improvement, the students, including the English major and non-English major, undergraduates and postgraduates, have achieved excellent performance in all kinds of speech contests, such as the provincial and national wide ones. The number of the prizes has come to more than 100 in these two years and many students got the First, Second and the Third prize in different contests for undergraduates and postgraduates.

All of these data proved again the effect of the "Cohesion-focused Teaching Method". Nowadays, with the development of globalization, English has become a universal language which supplies a tool for people's communication. Communication will be the first goal of learning a language, which matches the first one in
American 5C (Communication, cultures, connections, comparisons and communities) learning standards.

\section{ACKNOWLEDGMENT}

There are many people to whom I am very grateful. First of all, I'd like express my heart-felt thanks to Professor Ren Suzhen, Asststant Professor Huo Xinghua. Then, I would like to thank my husband, Wang Tianlong who gave me a lot of good suggestions. Further acknowledgements should be given to those students who attended the research.

\section{REFERENCES}

[1] Celce-Murcia, M. 1999. "Discourse Analyses and the, Teaching of Listening”. In G. Cook \& B. Seidlhofer (eds.), Principles and Practice in Applied Linguistics. Shanghai: Oxford University Press.

[2] Chaudron, C. \& J.C. Richards. The Effect of Discourse,Markers on the Comprehension of Lectures. Applied,linguistics, 7, 2.

[3] Ellis, R. 1994. The Study of Second Language Acquisition. Shanghai: Shanghai Foreign Language Education Press.

[4] Halliday, M.A.K. \& R. Hasan. 1976, Cohesion in English.London: Longman.

[5] Halliday, M. A. K. 1985. An Introduction to Functional Grammar. London: Edward Arnold.

[6] Halliday, M.A.K. \& R. Hasan. 1985. Language, Context and Text . Victoria: Deakin University Press.

[7] Rost, M. 1992. Listening in Language Learning. London: Longman.

[8] Rost, M. 1994, Introducing Listening. London: Penguin. 